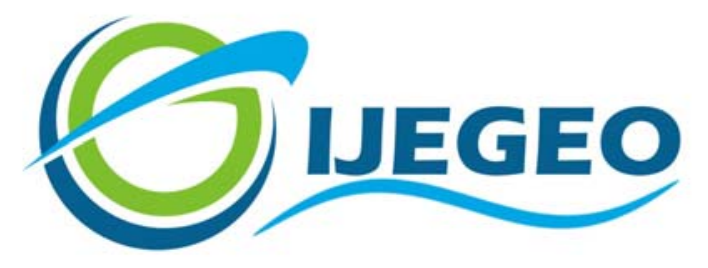

International Journal of Environment and Geoinformatics (IJEGEO) is an international, multidisciplinary, peer reviewed, open access journal.

\title{
Alien Benthic Foraminifers from Turkish Strait System
}

\section{Engin Meriç, M. Baki Yokeş, Zeki Ü. Yümün, Mustafa Eryılmaz and Fulya Yücesoy-Eryılmaz}

\author{
Editors \\ Prof. Dr. Cem Gazioğlu, Prof. Dr. Dursun Zafer Şeker, Prof. Dr. Ayşegül Tanık, \\ Prof. Dr. Şinasi Kaya, Assist. Prof. Dr. Volkan Demir
}

\section{Scientific Committee (2018)}

Assist. Prof. Dr. Abdullah Aksu, Prof. Dr. Bedri Alpar, Prof. Dr. Gülşen Altuğ, Prof. Dr. Lale Balas, Prof. Dr. Can Balas, Prof. Dr. Levent Bat, Prof. Dr. Bülent Bayram, Prof. Dr. Nuray Çağlar, Prof. Dr. Jadunandan Dash, Prof. Dr. A. Evren Erginal, Assoc. Prof. Dr. Ali Ertürk, Dr. Dieter Fritsch, Dr. Amin Gharehbaghi, Assoc. Prof. Dr. Tolga Görüm, Prof. Dr. Melike Gürel, Dr. Hakan Kaya, Prof. Dr. Fatmagül Kılıç, Assoc. Prof. Dr. Maged Marghany, Prof. Dr. Nebiye Musaoğlu, Prof. Dr. Masafumi Nakagawa, Prof. Dr. Haluk Özener, Prof. Dr. Erol Sarı, Prof. Dr. Elif Sertel, Prof. Dr. Nüket Sivri, Assoc. Prof. Dr. Füsun Balık Şanlı, Prof. Dr. Uğur Şanlı, Assoc. Prof. Dr. Hasan Özdemir, Prof. Dr. Taşkın Kavzoğlu Assoc. Prof. Dr. Oral Yağcı, Prof. Dr. Seyfettin Taş, Assoc. Prof. Dr. Ömer Suat Taşkın, Assoc. Prof. Dr. İ. Noyan Yılmaz, Assist. Prof. Dr. Baki Yokeş, Assit. Prof. Dr. Sibel Zeki 


\title{
Alien Benthic Foraminifers from Turkish Strait System
}

\author{
Engin Meriç ${ }^{1}$, M. Baki Yokeş ${ }^{2 *}$ Zeki Ü. Yümün ${ }^{3}$, Mustafa Eryılmaz $^{4}$, Fulya \\ Yücesoy-Eryılmaz ${ }^{4}$
}

${ }^{1}$ Moda Hüseyin Bey Sokak No: 15/4, 34710 KADIKOY, ISTANBUL-TR

${ }^{2}$ AMBRD Laboratories Hanımefendi Sokak, No: 160/9 34384, SISLI, İSTANBUL-TR

${ }^{3}$ Namık Kemal University, Faculty of Engineering, Department of Environmental Engineering, 59860, ÇORLU, TEKIRDAĞ-TR

${ }^{4}$ Mersin University, Faculty of Engineering, Department of Geological Engineering, 33343, Çiftlikköy MERSİN-TR

*Corresponding author

Received 15 Dec 2017

E-mail :bakiyokes@gmail.com

\begin{abstract}
The Sea of Marmara is under the influence of the Black Sea and the Mediterranean. The salinity difference between these two seas causes the formation of two-layer stratification in the Sea of Marmara, an upper layer formed by the fresh waters of the Black Sea and a denser layer formed below $25 \mathrm{~m}$ of depth, by the more saline waters of the Mediterranean. The salinity difference, together with the seasonally changing meteorological events are the major factors which shape the main current system. The Mediterranean waters enter the Dardanelles cross the Sea of Marmara and flows into the Black Sea via İstanbul Strait, which enables the dispersion of the alien foraminifer species already established on the Aegean coasts into the Sea of Marmara. Besides, the Sea of Marmara includes important harbors, suggesting that there is an extensive pressure of alien species introduced by ballast waters. In this study, 322 sediment samples, obtained from different localities in Dardanelles, İstanbul Strait and Sea of Marmara, were investigated for the alien foraminifer species. The results are combined with the previous records in the literature for creating an alien foraminifer checklist for the Sea of Marmara. 10 alien foraminifer species belonging to 9 genera were found in Dardanelles, 32 alien species from 28 genera in the Sea of Marmara, and only 2 alien species from 2 genera were found in İstanbul Strait. Majority of these alien species have Indo-Pacific or Atlantic origin, suggesting that shipping may be the most possible mode of introduction. But it is also observed that some of the Indo-Pacific originated species which were introduced Suez Canal and formed established populations along the Turkish coastline are also found in Dardanelles, indicating that major currents systems are also playing a role in the dispersion patterns of the alien foraminifers in the Sea of Marmara. Another important factor may be the thermal submarine springs found on the bottom of the Sea of Marmara, which may create suitable environmental conditions and enhance the establishment of thermophilic alien species.
\end{abstract}

Keywords: Foraminifers, Alien, Turkish Strait System, Istanbul Strait, Dardanelles

\section{Introduction}

Sea of Marmara is an inner sea which covers an area of $11,200 \mathrm{~km}^{2}$ and is connected to Black Sea via İstanbul Strait, to Aegean Sea via Dardanelles. It is divided into two regions; the Northern Shelf starts from Gallipoli and extends towards Gulf of İzmit, whereas Southern Shelf lays between Karabiga and Gulf of Gemlik. Four pits with approximately 1200 $\mathrm{m}$ depth are located between the two shelves (Figure 1).
Salinity difference between the Black Sea and the Mediterranean results in the stratification of the water column in the straits (İstanbul and Dardanelles) and also in the Sea of Marmara. This stratification plays the major role in shaping the current system. In İstanbul Strait, fresh waters of Black Sea (salinity \%o16-18) flow towards the Sea of Marmara and then to the Aegean Sea via Dardanelles on the surface. However, more saline and dense waters of the Mediterranean (salinity \%038-39) flows towards the Black Sea at the bottom (Figures 2 and 3). 
Due to the diffusion between layers, the salinities of the surface and bottom layers reaches to $\% 22-24$ and $\% 36$, respectively. The halocline layer between these two layers are formed around $25 \mathrm{~m}$ depth (Eryllmaz et al., 2000; Eryılmaz and Yücesoy Eryılmaz, 2003). The upper layer circulation in the Sea of Marmara is anti-cyclonic and caused by the water level difference between the Black Sea and the Aegean Sea (Ünlüata et al, 1990; Beşiktepe et al, 1994, 2000; Erdik and Beji, 2018). On the other hand, changes in the meteorological parameters, amount of rain, speed and direction of the winds can also affect the currents and may result in the formation of local deviations in the main current systems.

Benthic foraminifer assemblages in the Sea of Marmara have been studied by many researchers and a rich foraminifer fauna, including considerable amounts of alien genera and species have been reported. In the framework of the present study, 322 sediment samples from northern and southern coasts of the Sea of Marmara (Figure 4) investigated for alien foraminifer species and previous records in the literature are reviewed for constructing an alien foraminifer checklist for the Sea of Marmara.

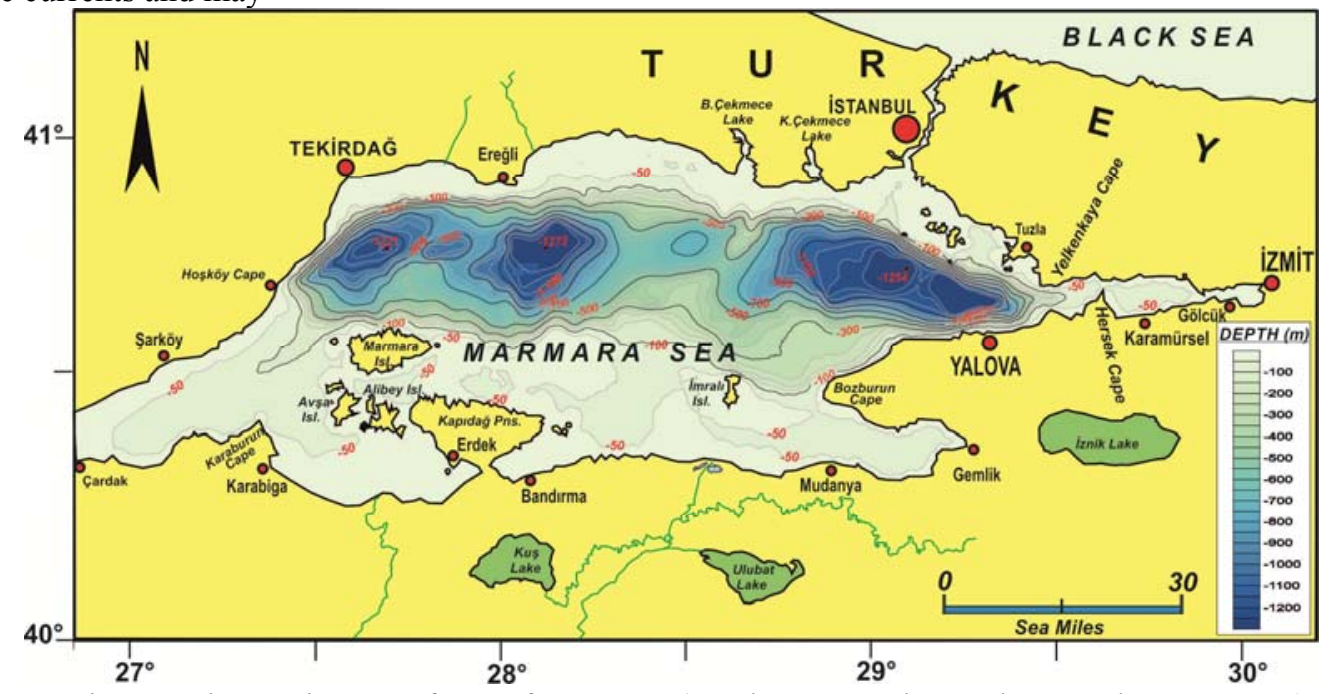

Fig 1. Bathymetric map of Sea of Marmara (Eryılmaz, 1995b; Eryılmaz and Kirca, 1998).

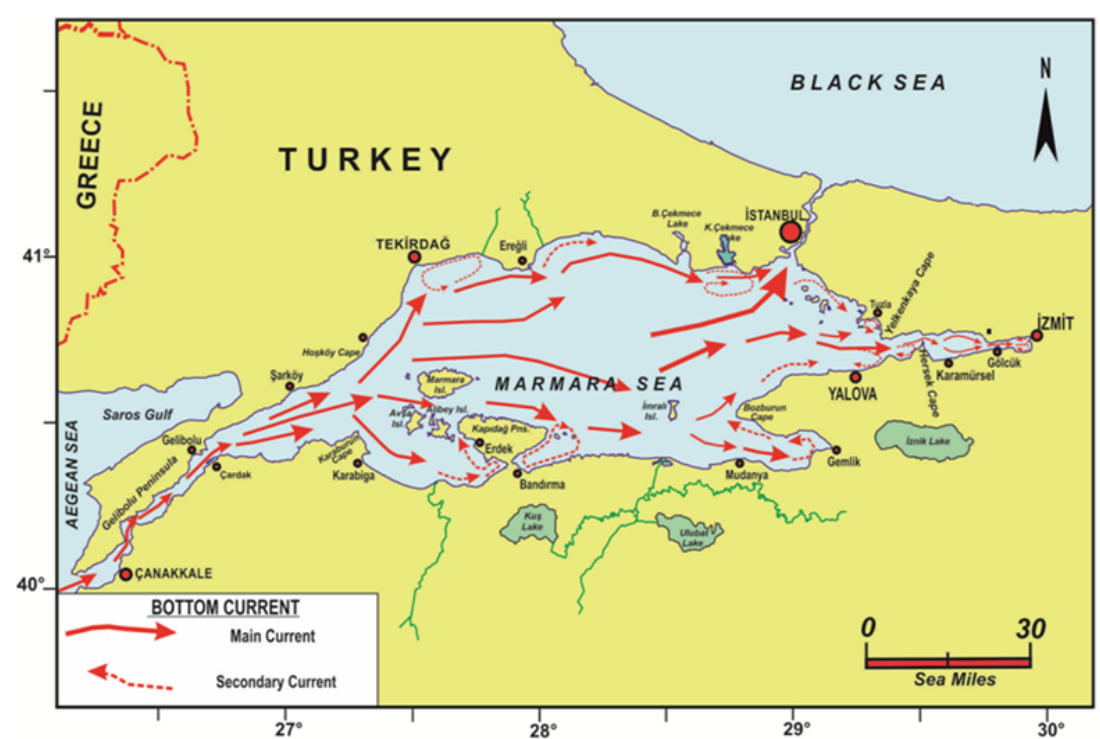

Figure 2. Bottom currents in Sea of Marmara (Ery1lmaz, 1999). 


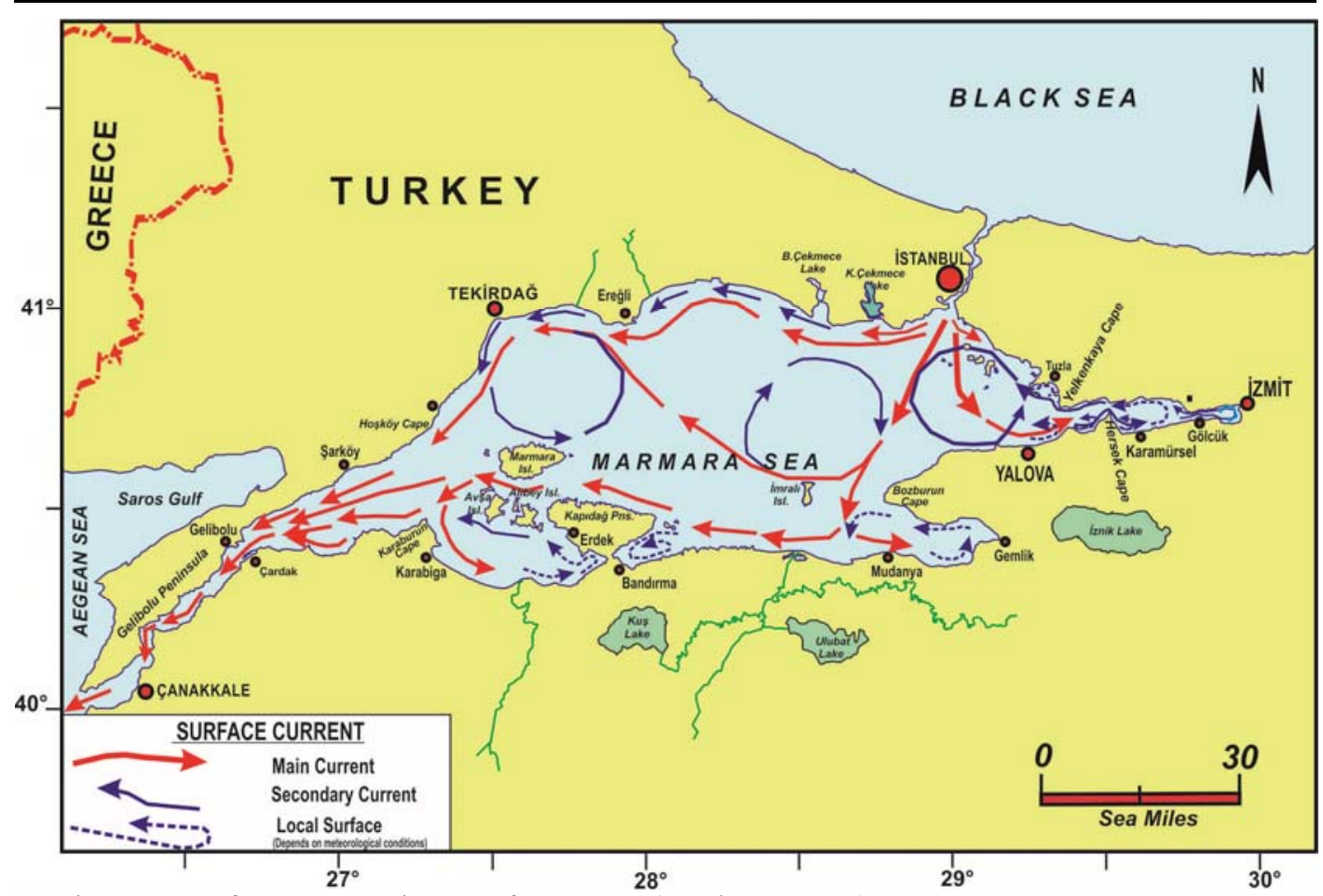

Figure 3. Surface currents in Sea of Marmara (Eryllmaz, 1999).

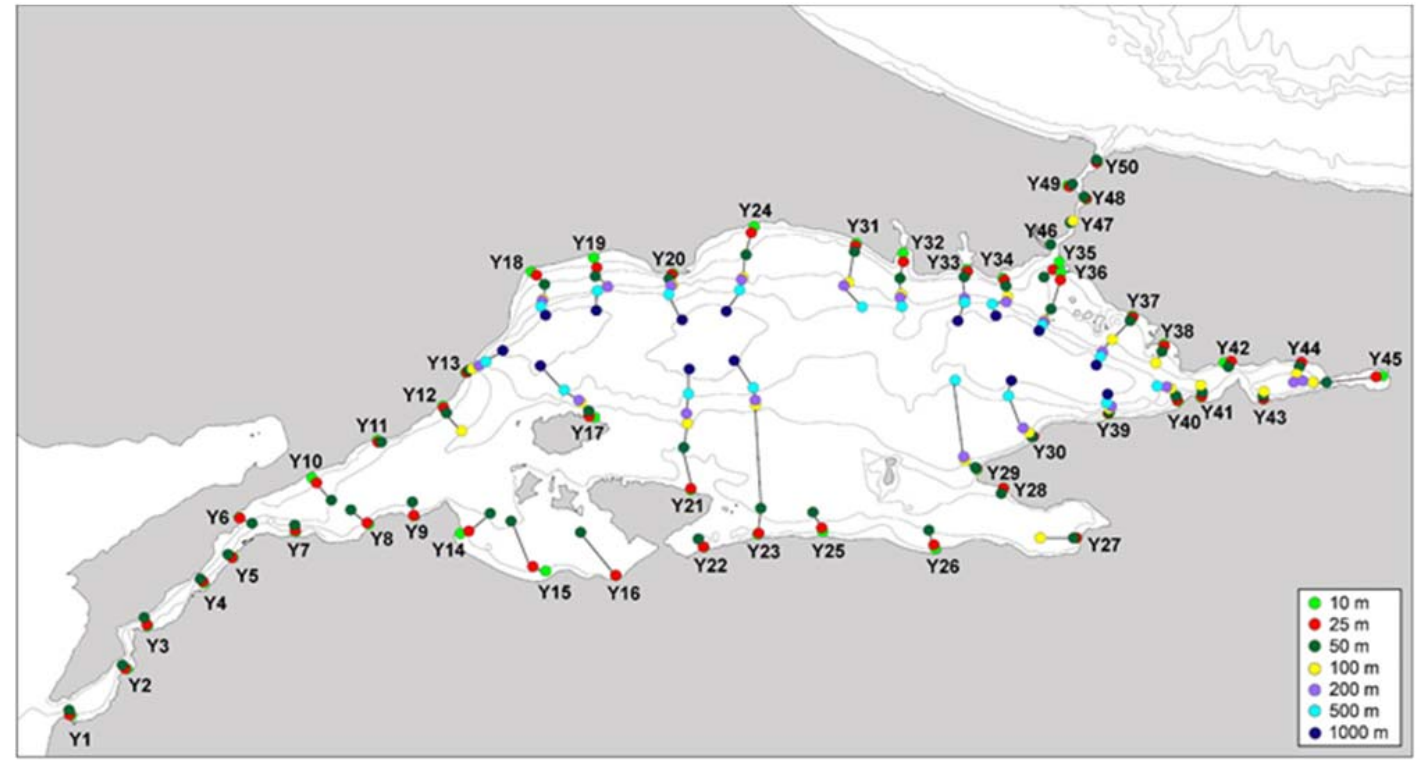

Figure 4. Locations and depths of the stations investigated in the scope of TÜBİTAK Project no: $111 \mathrm{Y} 268$.

\section{Results}

The distribution patterns of the alien foraminifers have been found as follows: Adercotryma glomeratum (Brady) (Kırc1Elmas, 2013; Kırcı-Elmas and Meriç, 2016) deep basin, Textularia cushmani Said (Kırc1Elmas, 2013; Kırcı-Elmas and Meriç, 2016) Southern Shelf, Cornuspiroides striolata (Brady) (Sakınç, 2008, pl. 2, fig. 10; Fig. 5, Y9; Kırc1-Elmas, 2013, Kırc1-Elmas and Meriç, 2016) Southern Shelf, Adelosina longirostra 
(d'Orbigny) (Kirc1-Elmas, 2013; Kırc1-Elmas and Meriç, 2016) Northern and Southern Shelves, Istanbul Strait, A. milletti Wiesner (Phipps et al., 2010) Northern Shelf, Spiroloculina angulata Cushman (Kırc1-Elmas, 2013, Kırcı-Elmas and Meriç, 2016) Southern Shelf, S. antillarum d'Orbigny (Meriç et al., 2009; Kirc1-Elmas, 2013; Kurc1-Elmas and Meriç. 2016) Dardanelles, Quinqueloculina parvula Schlumberger (Kırc1-Elmas, 2013; Kırc1-Elmas and Meriç, 2016) Northern and Southern Shelves, deep basin and Istanbul Strait, Biloculinella cylindrica Todd (Kurc1Elmas, 2013; Kırc1-Elmas and Meriç, 2016) deep basin, Ishamella apertura Buzas and Severin (Sakınç, 2008, pl. 9, figs. 1, 2) Northern Shelf, Peneroplis pertusus (Forskal) (Meriç et al., 2009, table 2b; Gürseler et al., 2014; Gülen et al., 2017; Yümün, 2017, pl. 1, figs. 13, 14) Southern Shelf coast of Bandirma, Gulf of Erdek and Gulf of Gemlik, P. planatus (Fichtel and Moll) (Gürseler et al, 2014) Gulf of Erdek, northeast of Kapıdağ Peninsula Southern Shelf, Coscinospira hemprichii Ehrenberg (Gürseler et al., 2014) Gulf of Erdek Southern Shelf, Dentalina albatrossi (Cushman) (Kirc1-Elmas, 2013; Kirc1-Elmas and Meriç, 2016; Fig. 5, Y1, Y9, Y14, Y19, Y24, Y33) Dardanelles, Northern and Southern Shelves, Dentalina vertebralis (Batsch) (Sakınç, 2008; Fig. 5, Y1, Y14, Y17) Dardanelles and Southern Shelf, Astacolus crepidulus (Fichtel and Moll) (Sakınç , 2008, table 10, figs.5, 6; Kirc1-Elmas, 2013; Kırc1Elmas and Meriç, 2016) Dardanelles, Northern and Southern Shelves, Marginulina gummi Saidova (Kırc1-Elmas, 2013; Kırc1-Elmas and Meriç, 2016) Dardanelles and Southern Shelf, Polymorphina fistulosa (Cushman) (Kırc1Elmas, 2013; Kırc1-Elmas and Meriç, 2016; Yümün, 2017, pl. 2, figs. 18, 19) Dardanelles, north of Kapıdağ Peninsula, Southern Shelf, Cushmanina striatopunctata (Parker and Jones) (Sakınç, 2008, pl. 11, fig. 1; Kırc1-Elmas, 2013; Meriç et al., 2014, pl. 48, fig. 7; Kırcı-Elmas and Meriç, 2016) Dardanelles, Northern and Southern Shelves, Fissurina faba (Balkwill and Millett) (Kırc1-Elmas, 2013; Kırc1-Elmas and Meriç, 2016) Southern Shelf, Stainforthia concava (Hoeglund) (Sakınç, 2008, pl. 13, figs. 3, 4; Kirc1-Elmas, 2013; Kirc1-Elmas and Meriç, 2016) Northern and Southern Shelves, Bulimina denudata Cushman and Parker (Kırc1-
Elmas, 2013; Kırc1-Elmas and Meriç, 2016) Southern Shelf, Bolivina striatula (Cushman) (Avşar, 2010) Northern Shelf, Siphonina tubulosa Cushman (K1rc1-Elmas, 2013; Kırc1Elmas and Meriç, 2016) deep basin, Cibicidoides pachyderma (Rzehak) (Kırc1Elmas, 2013; Kırc1-Elmas and Meriç, 2016) Dardanelles and Southern Shelf, ,Amphistegina lessonii d'Orbigny (Gürseler et al., 2014) northeast and southwest of Kapıdağ Peninsula, Southern Shelf, A. lobifera Larsen (Meriç et al, 2005, table 2; Kirc1-Elmas, 2013; Kırc1-Elmas and Meriç, 2016; Yümün, 2017. pl.2, fig. 1) coasts of Tekirdağ Northern Shelf and few specimens in 3 samples from west and northwest of Armutlu Peninsula on the Southern Shelf, Haynesina paucilocula (Cushman) (Kırc1-Elmas, 2013) Dardanelles, Northern and Southern Shelves, deep basin and Gulf of İzmit, Nonion subturgidum (Cushman) (Kırc1-Elmas, 2013; Kırc1-Elmas and Meriç, 2016) Southern Shelf, Melonis barleeanus (Williamson) Dardanelles, Northern and Southern Shelves, deep basin (Avşar, 2010; Kırc1-Elmas, 2013; Kırc1-Elmas and Meriç, 2016) , Buccella granulata (di Napoli Aliata) (Kırc1-Elmas, 2013; Kırcı-Elmas and Meriç, 2016) Northern and Southern Shelves, Faujasina carinata Bermudez (Sakınç, 2008, pl. 20, figs. 11, 12) Northern Shelf, Porosononion granosum (d'Orbigny) (Sakınç, 2008, pl. 19, figs. 9, 10) Southern Shelf (Meriç et al., 1995 and 2005; Sakınç, 2008; Meriç et al., 2009; Phipps et al., 2010; Avşar, 2010; Kırc1-Elmas, 2013; Meriç et al., 2014; Kırc1Elmas and Meriç, 2016; Yümün, 2017).

\section{Conclusions}

Alien foraminifer genera and species were abundantly observed in different locations in Dardanelles and Sea of Marmara. Until now, together with the results of the present study, 28 genera and 33 species have been found in the Turkish Straits System (Table 1). 10 alien species have been found in Dardanelles, whereas, only two alien species observed in İstanbul Strait, suggesting that some of the aliens which have been established in the Aegean Sea expanded their range of distributions, introduced via Dardanelles and dispersed in the Sea of Marmara by the currents (Figure 2 and 3). The distribution patterns of 
some of the alien foraminifers around the harbors, such as Tekirdağ, Bandırma and Gemlik, also suggests that some of the alien species should have been introduced to the Sea of Marmara by ballast waters, near to these harbors and dispersed to by the currents. The presence of hot water springs in the Sea of Marmara may create favorable environmental conditions for the Indo-Pacific originated aliens, which may enhance the dispersion of these thermophilic species (Figure 5).

Alien foraminifer species were observed either on the northern shelf, or on the southern shelf, or on both. Only few species were found on the deep basin. The İstanbul Strait is pretty much influenced by the Black Sea and the fresh water creates an unfavorable environment for the alien foraminifer species. To date, only Sorites orbiculus Ehrenberg has been recorded in the Black Sea, which has a very limited distribution between the exit of İstanbul Strait and Şile (Meriç et al., 2010).

The alien foraminifer species recorded in the Turkish Straits System included 28 genera and 33 species. Sakınç (2008) has mentioned that Cornuspiroides striolata (Brady) has been found in Gulf of Piran (Adriatic Sea), citing Cimerman and Langer (1991). However, the photograph given by Cimerman and Langer (1991) was showing a broken test fragment (Pl. 15 , fig. 8), which is absolutely not representing the genus and the species. Besides, Sakınç (2008) has noted that Ishamella apertura Buzas and Severin, Cushmanina striatopunctata (Parker and Jones), Stainforthia concava (Hoeglund) and Faujasina carinata d'Orbigny have not been recorded elsewhere in the Mediterranean, but has not made any comment on the possibility of their alien origin. The species given as Dentalina sp.1 by Sakınç (2008) which has been found on the southern shelf is actually Dentalina vertebralis (Batsch) observed on the Australian coasts (Yasinsi and Jones, 1995). Although Kirc1-Elmas (2013) has given most of the alien species and Yümün (2017) has recorded Polymorphina fistulosa (Cushman), Peneroplis pertusus (Forskal) and Amphistegina lobifera Larsen on the western coasts of Sea of Marmara, none of the authors has discussed their origin.

The amount of alien foraminifer genera and species recorded in the Sea of Marmara is considerable. Numerous hot and cold-water submarine springs are known to exist on the bottom of the Sea of Marmara (Figure 5). Besides the surface and bottom currents, these water exits are suggested to enhance the distribution and also the establishment of the thermophilic alien species. Future studies around these springs, as well as on the southern shelf, which is influenced by the currents from Dardanelles, will probably reveal more alien records.

\section{Acknowledgements}

This study was partially supported by TUBITAK (Project Number: 111Y268). The authors would like to thank staff of Ege University, Fisheries Faculty, Benthology Laboratory and Yunus $5 \mathrm{RV}$ for their invaluable help in collecting and preparation of samples and Levent Artüz (MAREM) for locating the submarine springs in the Sea of Marmara. 


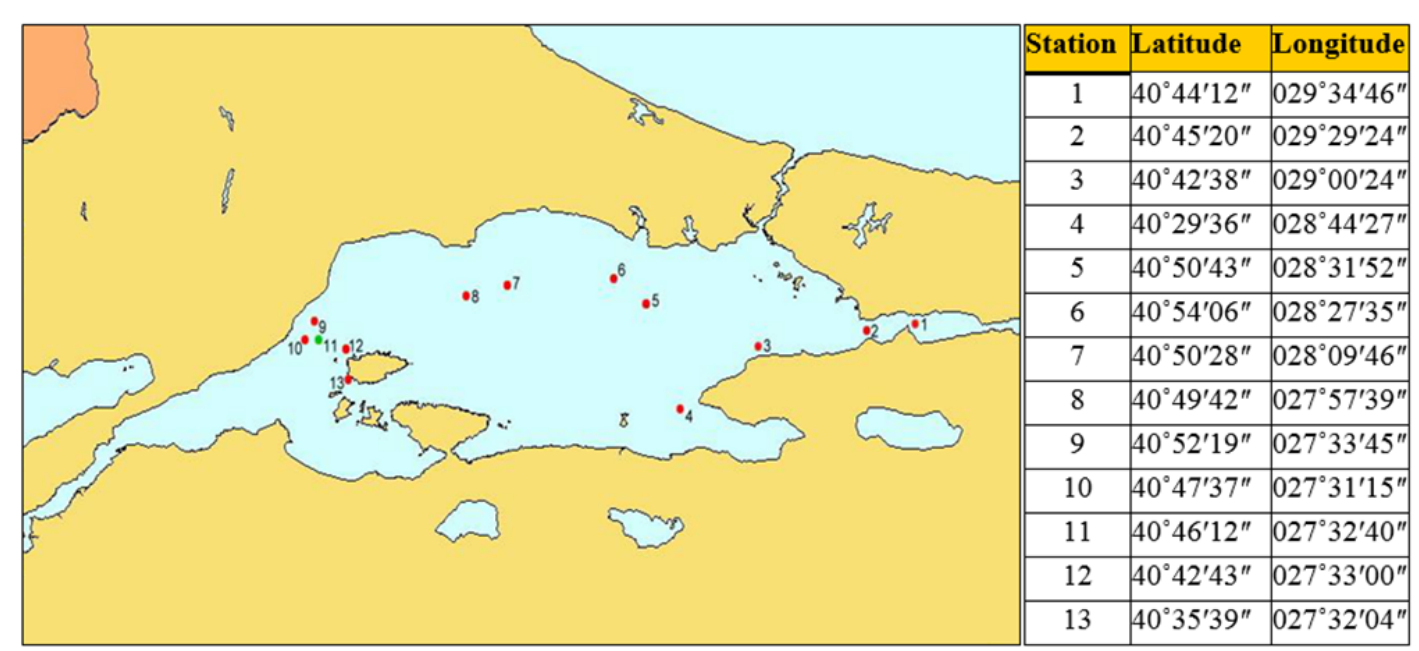

Figure 5. Locations and the coordinates of submarine springs $(O)$ and mud exits $(O)$ observed in the Sea of Marmara.

Table 1. Checklist of alien Benthic foraminifers from Turkish Strait System. Dar (Dardanelles), SM (Sea of Marmara), İst (İstanbul Strait), A (Atlantic Ocean), P (Pacific Ocean), I (Indian Ocean), IP (Indo-Pacific), C (circumglobal), SC (Suez Canal), Sh (ship), Re (Range expansion from Aegean or Levantine coastlines).

\begin{tabular}{|l|l|l|l|l|l|}
\hline Species & Dar & SM & İst & $\begin{array}{l}\text { Global } \\
\text { distribution }\end{array}$ & $\begin{array}{l}\text { Probable } \\
\text { vector }\end{array}$ \\
\hline Adercotryma glomeratum (Brady), & & + & & A, P & Sh \\
\hline Textularia cushmani Said, & & + & & I & Sh \\
\hline Cornuspiroides striolata (Brady) & & + & & A, P & Sh \\
\hline Adelosina longirostra (d'Orbigny) & & + & + & A, P & Sh \\
\hline Adelosina milletti Wiesner & & + & & P & SC+(Sh/Re) \\
\hline Spiroloculina angulata Cushman & & + & & P & SC+(Sh/Re) \\
\hline Spiroloculina antillarum d'Orbigny & + & & & A, P & (Sh/SC)+Re \\
\hline Quinqueloculina parvula Schlumberger & & + & + & A & Sh \\
\hline Biloculinella cylindrica Todd & & + & & A & Sh \\
\hline Ishamella apertura Buzas and Severin & & + & & A & Sh \\
\hline Peneroplis pertusus (Forskal) & & + & & A, P & SC+Re \\
\hline Peneroplis planatus (Fichtel and Moll) & & + & & IP & SC+Re \\
\hline Coscinospira hemprichii Ehrenberg & & + & & IP & SC+Re \\
\hline Dentalina albatrossi (Cushman) & + & + & & A, P & Sh+Re \\
\hline Dentalina vertebralis (Batsch) & + & + & & P & Sh \\
\hline Astacolus crepidulus (Fichtel and Moll) & + & + & & A, P & Sh \\
\hline $\begin{array}{l}\text { Marginulina gummi Saidova } \\
\text { Palymorphina fistulosa (Cushman) }\end{array}$ & + & + & & $\begin{array}{l}\text { Endemic to } \\
\text { Sh } \\
\text { New } \\
\text { Zealand }\end{array}$ \\
\hline $\begin{array}{l}\text { Cushmanina striatopunctata (Parker } \\
\text { and Jones) }\end{array}$ & + & + & & A, P & Sh \\
\hline Fissurina faba (Balkwill and Millet) & & + & & A & Sh \\
\hline Stainforthia concava (Hoeglund) & & + & & A, P & Sh \\
\hline $\begin{array}{l}\text { Bulimina denudata Cushman and } \\
\text { Parker }\end{array}$ & & + & & P & Sh \\
\hline Bolivina striatula (Cushman) & & + & & C & Sh? \\
\hline
\end{tabular}




\begin{tabular}{|l|l|l|l|l|l|}
\hline Siphonina tubulosa Cushman & & + & & C & Sh \\
\hline Cibicidoides pachyderma (Rzehak) & + & + & & A, P & Sh \\
\hline Amphistegina lessonii d'Orbigny & & + & & C & (SC/Sh)+Re \\
\hline Amphistegina lobifera Larsen & & + & & A, I & SC+Re \\
\hline Haynesina paucilocula (Cushman) & + & + & & A & Sh \\
\hline Nonion subturgidum (Cushman) & & + & & IP & Sh \\
\hline Melonis barleeanus (Williamson) & + & + & & A & Sh \\
\hline Buccella granulata (di Napoli Aliata) & & + & & A & Sh \\
\hline Faujasina carinata Bermudez & & + & & A & Sh \\
\hline Porosononion granosum (d'Orbigny) & & + & & A, P & Sh \\
\hline
\end{tabular}

\section{References}

Avşar, N. (2010) Benthic foraminiferal assemblages in the coastals environment of the northern Marmara shelf (NW Turkey). Micropaleontology, 56 (5), 495-506.

Beşiktepe, S., Sur, H.İ., Özsoy, E., Latif M.A., Oğuz, T. (2000). Marmara Denizi'nin Hidrografisi ve Dolaşımı. Marmara Denizi “2000” Sempozyumu, 11-12 Kasim 2000, Bildiriler Kitab1, s.314- 326, İstanbul.

Beşiktepe, S., Sur, H.İ., Özsoy, E., Latif M.A., Oğuz, T., Ünlüata, Ü. (1994). Circulation and hydrography of the Marmara Sea. Prog. Oceanography, 34: 285-334.

Çağlar, K. Ö. (1946) Türkiye maden suları ve kaplıcaları. Maden Tetkik ve Arama Enstitüsü yayınları, Seri B, No: 11, 791 s., Ankara.

Cimerman, F. and Langer,, M. R. (1991) Mediterranean foraminifera. Slovenska Akademija Znanosti in Umetnosti, Akademia Scientiarum et Artium Slovenica. 118 p., 93 plts., Ljubljana.

Erdik, T. and Beji, S. (2018).Statistical Analyses Wave Height and Wind Velocity Distributions for the Sea of Marmara. IJEGEO Vol 5(1): 76-83.

Eryılmaz M., Türker, A., Aydın, Ş. ve Kırca, Z. (2000). İstanbul Boğazında güncel çökel dağılımı. 1. Ulusal Deniz Bilimleri Konferans1, Editör: Z.Uysal, İ. Salihoğlu, (30 Mayıs-2 Haziran 2000), s. 281-283, 299 sayfa, ODTÜ, Ankara.

Eryılmaz, M. and Yücesoy Eryılmaz, F. (2003). Recent sediment distibution of the southwest Black Sea. Oceanography of the Eastern Mediterranean and Black Sea, (Similarities and differences of two interconnected basins), (Ed. A.Y1lmaz), p.944-947, ISBN: 975-288-451-2, Ankara.

Gülen, D., Sakınç, M., Yalçın, B., Özyiğit, İ.İ., Aygün, A., Çubuk, S., Yılmaz, N. (2017). Marmara Denizi'nin Değișen Oşinografik Şartlarının İzlenmesi Projesi (MAREM),
2016 Senesi Çalışma Verileri. İstanbul, 527 sayfa.

Gürseler, G., Gülen, D., Sakınç, M., Yalçın, B., Demir, G., Ökten, H. E., Kubanç, C., Kubanç, N., Tezcan, Ö. D., Çubuk, S., Sönmez, B., Yalçın, İ. E., Ceylan, A., Boz, B., Deniz, D., Turhan, H., Tanrıkulu, S., Korkmaz, T. (2014). Marmara Denizi'nin değişen oşinografik şartlarının izlenmesi projesi 2013 senesi çalışma verileri (Ön Raporlar). MAREM (Marmara Environmental Monitoring) Projesi. (Editör: M. Levent ARTÜZ). T. B. B. Yayınları No: 252, İstanbul.

Kirc1-Elmas, E. (2013) Benthic foraminiferal distribution (living and dead) from a permanently stratified marginal sea (Marmara Sea, Turkey). Journal of Foraminiferal Research, 43 (4), 340-360.

Kırc1-Elmas, E., Meriç, E. (2016) Foraminiferal fauna of the Sea of Marmara. In: The Sea of Marmara, Marine biodiversity, fisheries, conservation and governance, 401-417 (eds: E. Özsoy, M. N. Çağatay, N. Balkıs and B. Öztürk), 957 p., Turkish Marine Research Foundation, No: 42, İstanbul.

Meriç, E., Avşar, N., Nazik, A., Alpar, B., Yokeş, B., Barut, İ. F., Ünlü, S. (2005). Gemlik Körfezi yüzey çökellerinin foraminifer, ostrakod ve mollusk faunası, foraminifer kavkılarında gözlenen morfolojik anomaliler ile bölgenin sedimentolojik, hidrokimyasal ve biokimyasal özellikleri. M.T.A. Dergisi, 131, 21-48, Ankara.

Meriç, E., Avşar, N., Nazik, A., Yokeş, B., Ergin, M., Eryılmaz, M., Yücesoy-Eryılmaz, F., Gökaşan, E., Suner, F., Tur, H., Aydın, Ş., Dinçer, F. (2009). Çanakkale Boğazı'nın Güncel bentik foraminifer, ostrakod ve mollusk topluluğunu denetleyen faktörler ile çökel dağılımının jeokimyası. Türkiye 
Jeoloji Bülteni, 52 (2), 155-215, Ankara.

Meriç, E., Avşar, N., Nazik, A., Yokeş, M., Barut, İ. F., Eryılmaz, M., Kam, E., Taşkın, H., Başsarı, A., Dinçer, F., Bircan, C., Kaygun, A. (2012). Ilıca Koyu (Çeşmeİzmir) bentik foraminifer-ostrakod toplulukları ile Pasifik Okyanusu ve Kızıldeniz kökenli göçmen foraminiferler ve anormal bireyler. M.T.A. Dergisi, 145, 6278, Ankara.

Meriç, E., Yanko, V., Avşar, N. (1995). İzmit Körfezi (Hersek Burnu-Kaba Burun) Kuvaterner istifinin foraminifer faunası. İzmit Körfezi Kuvaterner İstifi (ed. E. Meriç), 105-151, İstanbul.

Meriç, E., Yokeş, B., Avşar, N., Dinçer, F. (2010) İndo-Pasifik kökenli göçmen foraminiferler Karadeniz'e ulaşıyorlar mı? TPJD Bülteni, 22 (2), 1-9, Ankara.

Meriç, E.,Avşar, N., Yokeş, M. B., Dinçer, F. (2014) Atlas of recent benthic foraminifera from Turkey. Micropaleontology, 60 (3-4), 211-398.

Phipps, M.D., Kaminski, M.A. and Aksu, A.E. (2010). Calcareous benthic foraminiferal biofacies along a depth transect on the southwestern Marmara shelf (Turkey). Micropaleontology 56 (3-4), 377-392.

Sakınç, M. (2008). Marmara Denizi Bentik Foraminiferleri: Sistematik ve Otoekoloji. Istanbul Teknik Üniversitesi Rektörlüğü, publication no: 1638, 134pp.

Ünlülata, Ü., Oğuz , T. , Latif, M. A. and Özsoy, E. (1990). On the Physical Oceanography of the Turkish Straits. The Physical Oceanography of Sea Straits Volume 318 of the series NATO ASI Series pp 25-60.

Yassini, I. and Jones, B. G. (1995). Foraminiferida and Ostracoda from estuarine and shelf environments on the southestern coast of Australia. The University of Wollongong Press, $269 \mathrm{p}$.

Yümün, Z. Ü. (2017). The effect of heavy metal pollution on foraminifera in the western Marmara Sea (Turkey). Journal of African Earth Sciences, 129, 346-365. 